\section{Sensitive thyrotrophin assays: excellent when properly used}

The honeymoon period of initial enthusiasm for a medical development is often followed by scepticism as its limitations become apparent. This has certainly been the experience with thyroid function tests, which to non-endocrinologists must seem to have proliferated almost exponentially. It is now three years since the introduction of sensitive immunometric assays for thyrotrophin capable of discriminating between serum specimens from hyperthyroid and euthyroid patients made the thyrotrophin releasing hormone test redundant. ${ }^{1}$ In some centres measuring thyrotrophin is now used as the first test of thyroid function; it has the advantage over thyroid hormone measurements of being unaffected by changes in the concentration or affinity of binding proteins and of identifying subclinical disease. No test is perfect, however, and caution is necessary in its interpretation.

Normal thyrotrophin values may be recorded in patients with thyroid failure secondary to pituitary or hypothalamic disease $^{2}$ and in some hyperthyroid patients with pituitary tumours that secrete thyrotrophin. ${ }^{3}$ Using a measurement of thyrotrophin as a screening test may cause these diagnoses to be missed, but they are rare and secondary hypothyroidism is usually associated with clinical features of other deficiencies of trophic hormones. Another occasional problem is that in some assays spuriously detectable concentrations of thyrotrophin are recorded in hyperthyroidism because antibodies in the patient's serum bind to the reagent antibodies. ${ }^{4}$ On the other hand, thyrotrophin concentrations may be undetectable in euthyroid women in early pregnancy ${ }^{5}$ and in patients with severe endogenous depression. ${ }^{6}$

The greatest source of concern, however, is in patients with non-thyroidal illness: in them biochemical assessment of thyroid function is notoriously difficult, particularly when kit methods for free thyroxine and triiodothyronine, using tracer analogues, are used. ${ }^{7}$ The newer thyrotrophin assays have greatly improved measurements in this group, ${ }^{8}$ but diagnostic specificity is still impaired because of the pathophysiological suppression of thyrotrophin in severe illness (particularly in those patients receiving treatment with corticosteroids and dopamine ${ }^{910}$ ) and the rise in thyrotrophin occasionally seen during recovery. ${ }^{11}$

Fortunately thyroid disease is not usually a clinical consideration in such patients, but in one large series of unselected admissions to an acute medical unit an undetectable thyrotrophin value was three times as likely to be caused by non-thyroidal illness as by hyperthyroidism and raised thyrotrophin was attributed as commonly to illness as to primary hypothyroidism. ${ }^{12}$ These studies in which thyroid investigations are performed on patients irrespective of the clinical suspicion of thyroid disease may test the specificity of an assay to unrealistic lengths. There is, however, a regrettable tendency to request thyroid function tests in all patients admitted to hospital, a practice that increases laboratory workload disproportionately in relation to the yield of thyroid disease. ${ }^{1314}$ It would be unfortunate if because of this policy measuring serum thyrotrophin were to be devalued; users must appreciate that abnormal results in patients with no clinical evidence of thyroid disease are not a fault of the assay but an accurate reflection of the physiological response of the thyrotroph to illness.

We strongly advise that thyroid function tests are not performed in ill patients unless there is a clear clinical suspicion of thyroid disease. Those who advocate screening all patients on admission should normally delay further investigation of an abnormal thyrotrophin measurement until the patient has recovered from the non-thyroidal illness.

A D TOFT

Senior lecturer

J SETH

University Departments of

Top grade biochemist

Medicine and Clinical Chemistry,

Royal Infirmary,

Edinburgh EH39YW

1 Seth J, Kellett HA, Caldwell G, et al. A sensitive immunoradiometric assay for serum TSH-a replacement for the TRH test? BrMed f 1984;289:1334-6.

Mori $\mathrm{T}$, Imura $\mathrm{H}$, Bito $\mathrm{S}$, et al. Clinical usefulness of a highly sensitive enzyme-immunoassay of TSH. Clin Endocrinol Oxford 1987;27:1-10.

3 Beck-Peccoz P, Piscitelli G, Medri G, Ballabio M, Faglia G. Thyroid test strategy. Lancet 1985;i:1456.

4 Marstein S. Caution against spuriously increased thyrotropin values as determined by two-site immunoradiometric assays. Clin Chem 1987;33:1290-1.

5 Gow SM, Kellett HA, Seth J, Sweeting VM, Toft AD, Beckett GJ. Limitations of new thyroid function tests in pregnancy. Clin Chim Acta 1985;152:325-33.

6 Piketty M-L, Talbot J-N, Askienazy S, Milhaud G. Clinical significance of a low concentration of thyrotropin: five immunometric "kit" assays compared. Clin Chem 1987;33:1237-41.

7 Melmed S, Geola FL, Reed AW, et al. A comparison of methods for assessing thyroid function in non-thyroidal illness. $f$ Clin Endocrinol Metab 1982;54:300-6.

8 John R, Evans PE, Scanlon MF, Hall R. Clinical value of immunoradiometric assay of thyrotropin for patients with non-thyroidal illness and taking various drugs. Clin Chem 1987;33:566-9.

for patients with non-thyroidal iliness and taking various drugs. Clin Chem 1987;33:566-9.
Wehmann RE, Gregerman RI, Burns WH, et al. Suppression of thyrotropin in the low thyroxine state of severe non-thyroidal illness. $N$ Engl f M Med 1985;312:546-52.

10 Faber J, Kirkegaard C, Rasmussen B, Westh H, Busch-Sorensen M, Jensen IW. Pituitary-thyroid axis in critical illness. F Clin Endocrinol Metab 1987;65:315-20.

11 Bacci V, Schussler GC, Kaplan TB. The relationship between serum triodothyronine and thyrotropin during systemic illness. F Clin Endocrinol Metab 1982;54:1229-35.

12 Spencer C, Eiger A, Shen D, et al. Specificity of sensitive assays of thyrotropin (TSH) used to screen for thyroid disease in hospitalized patients. Clin Chem 1987;33:1391-6.

13 White GH, Walmsley RN. Can the initial clinical assessment of thyroid function be improved? Lancet 1978;ii:933-4.

14 Drake JR, Miller DK, Evans RG. Cost-effectiveness of thyroid function tests. Arch Intern Med 1982;142:1810-2.

\section{AIDS: the need for data}

The urgent need for more and better data on infection with human immunodeficiency virus (HIV) was the strongest message to come out of the recent meeting of the Royal Statistical Society on the statistical aspects of HIV infection. It is because of this need that the society has supported both making the acquired immune deficiency syndrome (AIDS) a notifiable disease and the anonymous testing of blood samples for antibodies to HIV.

Statisticians have developed mathematical models of the transmission of HIV infection, but, Dr Valerie Isham of Imperial College explained, the models cannot reliably predict the spread of HIV infection without better data to feed into them. The models can be used, however, to identify which risk factors for spread are most important, and Professor Roy Anderson from Imperial College hoped that the existence of the models would stimulate doctors to collect good prospective data. We particularly need data on patterns of sexual activity. Available data relate to rates of changing sexual partners, but other data - on, for instance, the numbers using safe sex - may be more important. Some of those at the meeting thought that the models were unrealistically simple.

Dr Anne Johnson from the Middlesex Hospital emphasised the need for social and behavioural studies on representative groups - not only high risk groups but also heterosexuals. 